Boise State University

ScholarWorks

Communication Faculty Publications and

Presentations

Department of Communication

$4-1-2011$

\title{
Bombing at the Box Office: Reviewers' Responses to Agnosticism in Bill Maher's Religulous
}

Rick Clifton Moore

Boise State University 


\title{
Bombing at the Box Office: Reviewers’ Responses to Agnosticism in Bill Maher's Religulous
}

\author{
Rick Clifton Moore \\ Boise State University
}

\begin{abstract}
This paper examines reviewers' reactions to Bill Maher's documentary film Religulous as a way of beginning a discussion of media and religious hegemony. Hegemony theory posits that dominant ideology typically trumps contesting views, even when the latter do manage to leak through the system. Given this, one might expect that film reviewers serve as a second line of defense for entrenched worldviews. Here, however, a thematic analysis of reviews from major national newspapers reveals that critics provided only slight support to traditional religious views Maher challenges in his filmic plea for agnosticism.
\end{abstract}

There is in the world of comedy a plot structure that has traditionally been referred to with the non-inclusive label, "Character gets hoisted with his own petard." Most of us can envision this element by remembering the classic Warner Brothers Roadrunner and Coyote cartoons. In these, a scraggly canine antagonist did everything possible to destroy his avian counterpart. But, as any person who has seen a few episodes knows, in the end the hapless carnivore always becomes injured by the contraption he set out for his intended prey.

Though this might seem an odd metaphor for communication theory, there are many scholars who seem to hold a view of the American mass media environment that resembles the plot structure described above. They suggest that anyone who attempts to use dominant communication channels for messages that might be destructive of traditional ideas is typically thwarted. In fact, some argue that by the time those messages reach their audience they are twisted in a way that actually entrenches the status quo against which the message was intended. In short, the media product blows up in the creator's face. This is not to suggest that there are scholars who feel that this always occurs. Even those who are most distrustful of western media structures and practices believe that there are "leaks in the system."1 But, a thorough reading of the literature related to media indicates that many academics are attached to a view we can broadly label "hegemony" theory.

To further consider these issues, the following pages examine the extent to which media hegemony is evident within a specific context, the context of religious discourse. By thoroughly analyzing a particular case in which a media creator clearly intended to question widely held religious beliefs, it seeks to understand some of the ways in which controversial discourse might be thwarted, and, perhaps, instances in which it is not. The specific case investigated is a comedy film titled Religulous. Therein, Bill Maher, a popular humorist and talk show host, discusses whether religion might be limiting human potential. He even suggests that religion might be endangering civilization. As this is obviously a controversial idea that defies traditional American views of the importance of faith in community, one might wonder how such a film got made and widely distributed. Though this question is worthy of investigation, another is more the focus here. If the system is presumed to be set up so that controversial ideas do not have significant cultural impact, one might wonder whether there are additional means by which the power of an ideologically defiant film can be diminished. Here, the question is raised as to whether film reviews might be one such means. Simply put, did reviewers who wrote about Bill Maher's Religulous do so in a way that could cause the film to blow up in Maher's face rather than bring about the change he appears to desire?

\section{Hegemony And The Media}

The notion that United States mass media outlets predominantly serve the interest of those in power has deep and varied roots. Admittedly, there are fine differences between diverse schools of thought as to how media channels operate in the interests of dominant forces. Differences aside, however, the basic principle of the approach can be seen in sources such as Karl Marx. In his oft-quoted line from The German Ideology written in the mid nineteenth century he stated that, "The ideas of the ruling class are in every epoch the ruling ideas." 
Of course, at the time when Marx penned these words the modern mass media were in their infancy. The innovations of people such as Benjamin Day and James Gordon Bennett, who ushered in the world of modern commercial media, were just beginning to take hold. Later, in the mid-twentieth century, several social theorists added new dimensions to Marx's "ruling ideas" thesis. One of these is Antonio Gramsci, the Italian theorist who was imprisoned by the Fascist government and used his time to write down his thoughts on philosophy and politics. ${ }^{3}$ His notion of "hegemony" suggested that the ruling class stays in power by developing consent, not just by physical threat. Broadly similar, and equally popular as a basis to analyze the power of dominant ideas, has been the work of French philosopher Louis Althusser, who in the 1970s theorized it was through the means of “ideological state apparatuses" that capitalist society reproduces itself. Among these is the "communications ISA" that includes the modern media. ${ }^{4}$

As noted above, much work can be done to discern the differences in the ideas of Marx, Gramsci and Althusser. Such work is ongoing. What is also ongoing is a varied application of "hegemony theory," the notion that the ideas of the ruling class rise to the top and create consent. Whereas Marx was largely concerned with how ideas related to the means of production maintain their privileged status, today's scholars are interested in much beyond that. Continued work in the economic sphere has expanded to analysis of corporate hegemony. ${ }^{5}$ In the cultural sphere, hegemony theory is applied to a variety of other contexts. Worth noting here are the ways it is considered in relation to race/ethnicity ${ }^{6}$, gender $^{7}$ and especially to media portrayal of gays and lesbians. ${ }^{8}$

The last of these examples provides means to demonstrate how some theorists manifest a view of the world that suggests significant resistance to social change. Though popular opinion might envision liberal television writers and film directors disseminating messages that chip away at the status quo, mass communication scholars who take a hegemonic view are quite suspicious about any real social change. Some of their hesitation is based on the assumption that powerful people in the media do not want change and act in any way possible to stifle counter-hegemonic messages. ${ }^{9}$ More commonly, hegemony theorists believe there are structural constraints in media systems that help to protect the status quo. ${ }^{10}$

Regardless of the means by which this protection occurs, scholars perceive that media challenges typically fail to alter social structure. A few examples will demonstrate that this view is far from rare in academia. Elizabeth Ellsworth's analysis of reaction to the early 1980s film Personal Best exemplifies this. She describes how the movie brought a lesbian relationship to the mainstream, but (and the "but" of these studies is always crucial), "dominant reviewers typically resisted feminist interpretive strategies by acknowledging them, but deforming them in the service of sexist and heterosexist hegemony." 11 To cite another example, Danielle Mitchell analyzed the popular television show Will and Grace, a program which provided Americans with a weekly visit from several gay characters. Yet, as Mitchell explains, we must do more than look at how the film broke "heteronormative expectations," we must also "consider how its inclusionary cast of characters and its homocentric plots function to perpetuate inequity." 12 Another investigation of a seemingly positive media portrayal of gays in mainstream culture involved the cable series Queer Eye for the Straight Guy. Similar to the other studies cited here, the researchers begin with the potential for change. The television series would be presumed to help gays gain acceptance, as the show presents a sizable number of likable openly gay characters. But, according the researchers, a careful inspection of the program reveals a formula that allows the characters to briefly enter the mainstream, “only to be relegated to the Loft's cultural, geographical, and sexual exile by each episode’s end.”" ${ }^{13}$ Finally, Brenda Cooper and Edward Pease offer additional insights with their analysis of Ang Lee's 2005 film Brokeback Mountain. These researchers chose not to study the text of the film. Instead, they examined popular reviews of it. Counterintuitive as it might seem, the reviews for the motion picture were overwhelmingly positive. But, as we might expect in the realm of hegemony theory, researchers claim the frames that those reviews created "marginalized" the film's potential to bring about change in the way Americans view gays and lesbians. ${ }^{14}$

In all of these instances we see a consistent pattern. Though there appear to exist in the media bold practitioners who dare to present ideas that challenge the status quo, the messages they create never achieve any positive social change. Along these lines, Cooper and Pease lament the fact that Brokeback Mountain's release coincided with a number of successful state referenda outlawing homosexual unions. ${ }^{15}$ To return to the metaphor with which we began, the incendiary device is created, the fuse is lit, but when the dust and smoke settle, the target is still intact. 


\section{Media, Hegemony and Religulous}

The previous section demonstrated that a number of scholars claim the media are-wittingly or not—very protective of the status quo in economics, race relations and gender issues. Admittedly, these three are very important, broad aspects of society, and are worthy of study. Missing from the list, though, is religion. Few scholars have embarked on detailed analyses of how the media might play a role in protecting religion's normative status.

Just as there is a presumed dominant view in economics (capitalism), race (Caucasian), and gender (male heterosexism), there is a presumed dominant view in American religion. No less a scholar than the renowned post-structuralist Jacques Derrida has declared that the media operate under a Christian hegemony. ${ }^{16}$ And, a small number of scholars have investigated the extent to which media messages are hegemonic in regard to religion. ${ }^{17}$

Worth noting here is that there has indeed been significant research into the religiosity of media practitioners, but there is still ample disagreement as to the strength and/or validity of findings in that area. The research team of Lichter, Rothman and Lichter has presented a variety of data since 1986 to suggest that journalists and other media professionals (especially at the highest levels of the industry that the team refers to as "elite" media) are less attuned to traditional American religious practice than are members of the general public. ${ }^{18}$ They provide poll data and content analyses to support the claim. Marvin Olasky has provided historical data to make similar arguments. Even though American journalists were once very theologically grounded, according to Olasky, they began a move in the 1830s toward pantheism and materialism. Eventually, the press developed a strong anti-Christian bias. ${ }^{19}$ Meanwhile, however, two respected media/religion scholars have done extensive work that suggests otherwise. Mark Silk's book Unsecular Media provides thorough historical documentation to his view that mainstream media in the United States are quite reflective, even respective, of the religious soil in which they developed. ${ }^{20}$ Echoing his views is Doug Underwood, who has provided poll data to show that presumably anti-religious reporters actually adhere to beliefs that are very indebted to the Judeo-Christian tradition. ${ }^{21}$ In short, he attempts to show how "religious values, hidden though they may be, guide journalists in their thinking and their daily tasks." ${ }^{22}$ To sum up, previous research on whether journalists are religious folk is rather inconclusive.

Given this hazy background, the following analysis proposes that further clarity can be gained by analyzing media messages that are conclusively anti-religious. Such a message was made available with the release of Bill Maher's documentary comedy Religulous. Throughout the film, Maher (who says he is "big on doubt") challenges believers of various faiths to explain why they are religious. In the final scenes, he suggests that the world should abandon its attachment to old myths, and become more modern and rational. “Grow up or die,” he concludes.

In Religulous, then, an opportunity exists to examine the extent to which a counter-ideological message will be suffered by the system. And, given the fact that the medium for the message was film, we have an opportunity to extend the work of Cooper and Pease, who examined newspaper reviews of Brokeback Mountain to demonstrate how critics hogtied the counter-hegemonic message of that film. Stated simply, this research followed the lead of Cooper and Pease, analyzing how reviews "frame" a strongly counter-cultural motion picture. ${ }^{23}$ Given that hegemony theory suggests corporate "big media" exert the most cultural power, this study focused on reviews from the twenty newspapers with the highest circulation in the United States. ${ }^{24}$ To increase validity and reliability, a group of four graduate students in a Master's level class in media were shown each of the twenty reviews. They were then asked to develop consensus on whether the review was positive or negative, and to determine the main frames used by the reviewer.

\section{Tone and Frames}

Much of what has been presented thus far might suggest that movie reviewers are a second line of defense in ideological warfare. That is, when a leak in the system allows a counter-hegemonic film to be made, reviewers can lessen its impact by giving the production a bad review (and steering audiences away from it.)

Some might balk at this depiction, but it is an image portrayed clearly in the work of Cooper and Pease and other hegemony theorists. The popular conception of film reviewers as free spirits (and free agents) may be well established, but it runs contrary to hegemony theory in two ways. First, though many of us might think of film reviewers as mavericks, those with a Marxist view-hegemony theorists, among them-see few mavericks in the system. For example, Bettig and Hall, in their book Big Media, Big Money claim that film critics are just as vulnerable to corporate pressure as are journalists, leading to a "corruption of the reviewing process." ${ }^{25}$ Secondly, this corruption is a logical historical extension of hegemony theory if the theory accurately describes the way media work in capitalist societies. If 
scholars such as Gramsci are correct in assuming that the media are agents of social control, much of that "agency" may be moving from news media to other forms. After all, as "hard news" becomes a less powerful social force in society, dominant institutions that wish to continue to use media to maintain control must move their influence into more entertainment-oriented forms (such as movies and their reviews). Barring faith in Lazarsfeld's two-step flow theory of mass communication effects, if the audience for hard news continues to diminish, traditional news will have less hegemonic power in the future than in the recent past.

To return to the Wiley Coyote metaphor provided earlier, then, film reviewers may be able to serve a useful purpose in defending the established order from explosions. Viewed simplistically, they can steer audiences away from a film with a radical message. Seen in more sophisticated fashion, they can frame a film in such a way that its percussion is lessened. Either way, hegemony theory paints film critics as cultural bomb squads.

The following pages suggest that the extent to which reviewers performed their task was mixed. At the simplistic level, reviews of Religulous from the nation's largest newspapers were quite supportive of the production and did not show a tendency to steer audiences from it. Eleven of the twenty reviews scrutinized by graduate students were thought to have generally positive opinions of the film. Five were deemed to be evenly mixed between positive and negative, whereas four were generally negative. As for more sophisticated ways of de-fusing the film, analysis of such requires a review of the frames most often created. Three main frames were encountered and are analyzed below.

\section{Let Maher Be Maher}

Surprisingly, one of the most common frames reviewers used to talk about Religulous dealt with the film's maker more than the film itself. In the critiques analyzed here, discussion of the personality of the film's "host" (for lack of a better word), Bill Maher, was common. Indeed, it was often a dominant theme.

This makes perfect sense to those who follow American popular culture. Maher has been visible in the entertainment field for well over twenty years. To give a hint of this, one of the clips from Religulous shows him doing standup on The Tonight Show in the mid-1980s. Since those early years, he has taken a number of roles as a writer, actor, and producer. The most visible element of his celebrity identity is probably that he "plays himself"-as the situation is described on entertainment sites such as IMDB.com—on numerous talk shows. Several of those talk shows have been his own, namely Politically Incorrect and Real Time.

In his various appearances, Maher has developed a notable screen character, a character that reviewers perceived some filmgoers would like, some would not. As one aptly put it, the film "won't convert a dogged Bill Maher-hater to fanboy status." ${ }^{26}$ Another noted that most audience members should know what they are getting into before they arrive at the theater. Specifically, Michael Phillips of The Chicago Tribune wrote, "It's a fairly entertaining bash...It's also smug as all hell. No surprise there, given Maher's well-honed argumentative persona on his 'Real Time' HBO series." ${ }^{27}$ One way to envision the persona we're describing is "provocateur," 28 a term that one reviewer actually used.

This role Maher played appears to have succeeded for many reviewers as they recognized the value of self-assured comic provocation and its place in American culture. The presumption appears to be that humorists who invite the audience to critically examine their culture need to be a bit offensive. One reviewer wrote "He's an acerbic comedian and incisive critic, skilled at grinding sacred cows into hamburger." ${ }^{29}$ Another noted similarities between Maher's film and some of Mark Twain's writing. ${ }^{30}$ For a more recent allusion, one suggested that 1960s stand-up comedian Lenny Bruce—well known for his provocations against traditional morality— "would be proud."31

This is not to say that everyone likes a comedian in the mold of Bill Maher (or Lenny Bruce). A number of reviewers clearly shared their own dissatisfaction, or recognized the potential for audience revolt. As noted above, one said that the movie was entertaining but it was also "smug as all hell." Another wrote that Maher's "smugness makes him a frustrating guide for this kind of quest." ${ }^{32}$ A third explained why he and many other viewers might take to disliking the film. His description of Maher was, "He’s smug. He's arrogant. He doesn't listen. He's full of wisecracks, rides around in a nice car and acts as if everybody he meets is a complete idiot., ${ }^{33}$

The comments above demonstrate that critics were fully aware of the host's cantankerous manner. They do not delve into the comedian's predilection for veering into the subject of religion. But these two did go hand in hand, and are difficult to separate. One reviewer quipped that "Maher has long used religion as comic fodder." ${ }^{34}$ Another suggested that the comedian has "already established his position as an agnostic in his HBO comedy series." ${ }^{35}$ With similar 
warning, a third says that viewers of the show should be fully aware that the host "can be entertaining, smart and caustic about religion.” 36

As was the case with opinions about the filmmaker's smugness, though, these comments seemed to indicate that reviewers recognized who they were dealing with and knew they were not going to change Bill Maher. They could point out how arrogant the film made the host appear. Presumably, many readers were already prepared for that. On the other hand, these writers did have an opportunity to grade the comic and assess the extent to which his smug agnosticism helped him create an admirable production. But, some of that discussion relates to "what" the film is as much as it does to "who" made it. That represents another frame.

\section{Blessed Are the Joke Makers, for They Shall Be Called the Children of Hollywood}

One obvious way that reviewers framed Religulous in relation to "what" questions was a simple interrogation of what the film was. More specifically, their concerns addressed questions related to its genre. As was the case with "who" questions, many of the "what" questions did not seem to have significant bearing on how viewers would perceive the religious arguments of the movie. Others, however, brought issues of religious belief and practice to the forefront.

One common answer in the "What is it?" category was, “A documentary.” But many critics struggled a bit to envision Religulous as such because they appear to have preconceptions about what a documentary would look like. And this film did match their vision. Writing in The Dallas Morning News, for example, Tom Maurstad wrote, "More than any film in recent memory, Religulous defies pat categorization.” ${ }^{37}$ Another reviewer suggested that the film attempted to present itself as filling the documentary mold yet failed in doing so. The reviewer suggested that it was "a provocation, thinly disguised as a documentary"38 Another referred to it as a "quasi-documentary."39 One writer did a nice job of laying out the key questions around these issues by actually posing them in question form, writing, "But what is Religulous, exactly? Is it a documentary? Is it journalism? Is it a one-sided screed? Maybe, no and yes.”40 This last point seems to represent the sticky wicket for a large number of those who wrote about the film. If a documentary is a production in which real people are able to speak in their own voices, Maher only met the first of these criteria. Real people were indeed interviewed. The comedian racked up a few frequent flier miles in order to record the voices of a variety of correspondents. The second criterion posed greater problems, however. There was great disagreement as to whether any of those voices could be heard.

A small number of writers seem to have felt that Maher did a reasonable job of allowing people to talk. They even intimate that the comedian was willing to listen and to allow for an open airing of ideas. One scribe suggested that this required Maher to walk a fine line. He wrote, "Statements spouted as fact are disputed, but Maher tries for a dialogue." 41 Another wrote of the host that "he seems to genuinely want to ask questions about the sometimes contradictory nature of religion and faith." 42 And, given the fact that the film was released at a time when presidential candidates were often asked about their views on matters of faith, one writer made reference to the film's role in this arena. He claimed it to be a “minor, but valuable, contribution to our election-season national debate." 43

But such words stand in stark contrast to those shared by a number of writers who clearly believe that little dialogue (or true debate) took place. For example, Stephen Whitty, writing in The Star-Ledger suggested that in spite of Maher's "genuflections toward free inquiry and rational debate," the filmmaker was "as close-minded as any of the preachers he despises." 44 Another reviewer, from The San Francisco Chronicle, said that Maher was "not interested in talking." 45 A third indicated that the comedian and his film "mistake mockery for a form of communication." 46 A fourth suggested the film was flawed because its producer merely paid "semi-polite lip service" to those whom he interviewed. ${ }^{47}$ These perceptions differed so much from those expressed in the immediately preceding paragraph that one wonders if reviewers even watched the same film. Whereas The Arizona Republic's Bill Goodykoontz (cited earlier) believed that Maher "seems to genuinely want to ask questions," Wesley Morris of The Boston Globe believed "Maher is not looking for answers. He’s looking for targets.”

This last point provides an apt transition to another frame on which there was significant dissent. To put it in the form of a question, "Who, exactly, were Maher's targets?" Or, with a different interrogative, "What was this movie really about?" 
For some, it was about “organized religion.” In spite of the fact that Maher never uses the term in Religulous, eight of the twenty reviewers whose work was analyzed here so described what they perceived the true subject of the film to be. Specifically, they wrote the following:

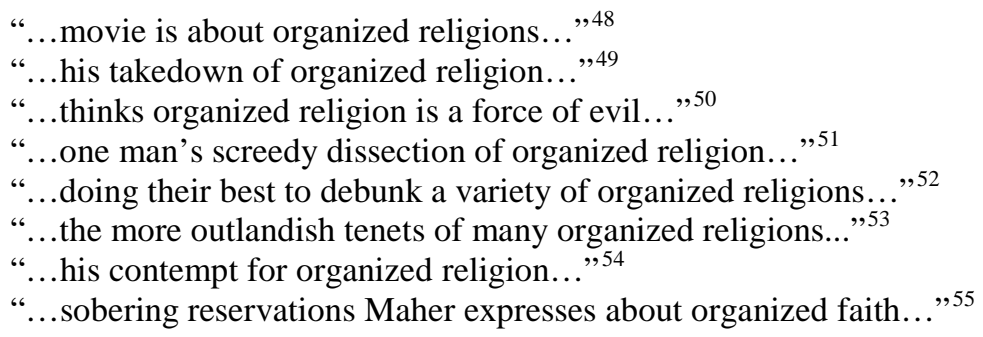

Similar to this “organized religion” frame, some writers used slightly different concepts to suggest that Maher's investigation was an examination a limited range of faith. Four used a variation of the word "fundamentalist" to describe the narrower topic they perceived the film was about. ${ }^{56}$ To provide one concrete example, a critic wrote, "Unless you're an easily offended fundamentalist - in other words, Maher's prime target and interview subject hereyou'll probably laugh at something in 'Religulous'." 57 Others also suggested that Maher was addressing a subset of the human religious experience, but there was no consistency to their terminology. One commented that the film was about "the gullibility of true believers" ${ }^{58}$ Another said the topic was "religious extremists of all faiths." 59 Finally, another wrote “Anyone affiliated with a Big Important Religion should brace for a sound thrashing.",60

In closing the discussion of what kind of film this was and what it was about, one other frame needs mentioning here. A conception of Religulous that was shared by many reviewers was that it was not one film but two. A good part of the film's 90 minutes is devoted to Maher asking pointed questions and cracking jokes. But, at a certain point, he drops much of the humor and begins to do something that might seem odd in an anti-religion film, he begins to preach. At least, that's what many of the reviewers perceived. Claudia Puig, for example, in the nation's most widely circulated paper, wrote, "While most of the movie is entertaining and illuminating, it falters toward the end, when its lighthearted tone grows ominous and preachy.” Others said, “"Maher's sense of humor deserts him in the end...," ${ }^{\text {" }}$ or, "Maher drops the joking tone in the end." 62 Two reviewers discussed this change of tone in relation to the certainty of belief, finding it a bit troubling that Maher spends the first part of the film expressing doubt and then ends with a tone of extreme confidence in his knowledge. ${ }^{63}$

This is not to say that reviewers wanted Maher to make an exclusively serious film about religion. The reviewers noted above simply had difficulty putting the two parts of the film together. In a similar way, another writer stated that Maher was working with a "serious idea" and that much of the humor "undercut" its success. ${ }^{64}$ But many of the critics seemed to comfortably bear with the tension between comedy and serious intent. One suggested that Maher's sarcasm was convincing and that the finale was "something to consider." 65 Another noted that Maher "demands to be taken seriously, even as he is determined to make us laugh.”66 Yet another expressed a positive attitude toward the two parts, suggesting that the serious ending was "a stern conclusion to a rollicking sermon.” ${ }^{7}$ Finally, Neely Tucker, of The Washington Post, provided a note on the film's conclusion that summarizes much of what has been written in this section. After at one point in the essay stating that Maher is "often laceratingly funny," she notes the change at the end of the film but shows a willingness to bear with it. As she describes this:

“'Grow up,' Maher admonishes viewers at the close, when he gets alarmingly serious. It might be good advice for him to follow -- but only if he can bring along his sense of humor. No reason to leave that behind." 68

\section{Like Shooting Loaves and Fishes in a Barrel}

If one of the dominant frames we have encountered dealt with the "who" of Religulous and another dealt with the "what" of the film, it makes perfect sense that another might deal with the "how." The "how" relates to execution and that is the focus of many popular reviewers as they critique films for readers who want advice on the quality of the cinematic experience. How did the filmmaker approach this project and to what extent was the approach wise and successful? Indeed, one of the most recognizable contemporary film reviewers, Roger Ebert, in the process of writing about the project stated, "This review is going to depend on one of my own deeply held beliefs: It's not what the movie is about, it's how it's about it." ${ }^{69}$ True to his word, Ebert gives a one sentence description of what the film is about 
(Maher's views on religion) and devotes the rest of the essay to how Maher deals with the subject he has chosen. According to Ebert, Maher talks with adherents of different faiths. But, says the Chicago Sun-Times reviewer, maybe "talks with" is not a very accurate reflection. Upon further consideration, Ebert decides the best description of the motion picture is that Maher chooses the religious adherents for his film and then "lines them up and shoots them down.”

Not only is Ebert's general approach ("how?” as opposed to “what?”) a frame for many of the reviews described here, the specific approach is as well. Numerous reviewers apparently decided with the dean of the critics that one of the most important points of discussion regarding Religulous was how Maher treated his interviewees. Did lining them up and shooting them down help the movie succeed? On this last point, reviewers had very different opinions.

Some reviewers seemed to take a rather amoral approach to Maher's shooting rampage. One, who elsewhere in his review praised the comedian for being "in top form," ${ }^{70}$ suggested that the film challenged religious belief by "bringing up easy-to-ridicule subjects, including televangelism, Christian amusement parks, and the way Jews find loopholes to

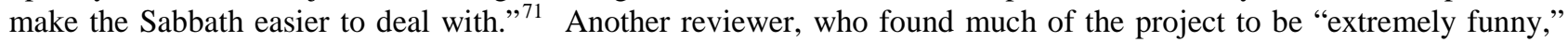
described how believers were coaxed to appear foolish as they provided weak responses to Maher's "friendly interrogations." 72 Certainly, we cannot hold culpable an "inquiring reporter" (as this reviewer described the host) who uses such soft tactics.

Other critics were much less favorable, and, perhaps, more defensive of the religion the filmmaker was interrogating. They even went so far as to question Maher's sincerity. Ironically, in doing so they also denigrated the religious folk who populated the film. To describe the filmmaker's tactics, they used terms like "stacking the deck" "73 or "shooting fish in a barrel" ${ }^{\prime 74}$ and in doing so suggested that the filmmaker was not really making a solid case for agnosticism. For example, one reviewer wrote, "So Maher scores points debating Christian theology with a guy who plays Jesus in a theme park? Impressive!” ${ }^{, 5}$ In writing this, however, the reviewers also inflicted a second layer of pain on those who had been battered on screen by the comedian. They intimated that these believers were dumb and simple (Maher "prefers to avoid the smart and the sophisticated" ${ }^{76}$ ) or "small fish.,"77 Further, Maher's interviewees are referred to with terms such as "marginal ministers" and "inarticulate eccentrics.",78 They are considered to be "below his weight class" or "amateurs" compared to the provocateur who has debated on national television for years. ${ }^{79}$

Again, this did not mean reviewers rejected Maher's key points. Nor did it mean that his ripostes were not funny. Reviewers were simply communicating a slight malaise they felt at fully enjoying these exchanges. Roger Ebert stated that he felt "guilty pleasure" at watching the interviews. The guilt of some appears to have reached a level where it actually diminished their pleasure, even if only slightly. One reviewer wrote, "it's difficult to watch the film without feeling for these poor individuals who just happened to have stumbled in front of the camera." ${ }^{\circ 0}$

What reservations the critic had, then, were not related to the subject, nor to the success of the humor, but to the treatment of humans who were victims thereof.

Another group, however, had a similar perception of the facts (that Maher interviewed people who were easy targets), but a different interpretation. They saw this as an aesthetic matter, not a moral one. For example, one reviewer wrote, "you may wish he'd set up his straight men and women in a way that doesn't merely score the cheapest possible laughs" ${ }^{81}$ Another suggested the filmmaker devoted too much attention to "people who operate on the fringe of religion, some odd and some just plain crazy." ${ }^{82}$ The reviewer did not suggest that this was inherently wrong. Rather, it is "too easy." And, the "easy" theme was reiterated by another, who said of the comedian, "because he wants to be amusing above all else, he takes his questions not to sober religious thinkers but to the assorted fruits and nuts that populate the fringes of religion." ${ }^{83}$ Extending on this idea, he continued:

"Rather than talk to Bishop Desmond Tutu -- hey, how much fun would that be? -- he goes out and about, scouring the globe for people whose responses to his qualms will make facile cinema." 84

A pair of other writers took the Desmond Tutu idea a bit more seriously, suggesting that some people who were not interviewed might be appropriate subjects. One offered that Rick Warren or Tony Perkins might have been good foils for Maher's wit. ${ }^{85}$ Another made a similar, but more general suggestion, noting that Maher "never talks with theologians or rabbis or pastors." ${ }^{, 86}$ 
A larger group of reviewers did something quite different than this. They suggested that the film included within its frames a refreshing alternative, to the "inarticulate eccentrics" Maher depended on. Specifically, they seemed to indicate that the antidote to the fringe religious adherents interviewed by the host were two Catholic priests in Religulous who provided a respite from what reviewers apparently perceived as a cavalcade of crazies. These two individuals were church Latin scholar Reginald Foster and George Coyne of the Vatican observatory. Eight of the twenty reviewers analyzed here made explicit reference to the pair, and all used positive terms to describe them. Moreover, they consistently suggested that these two posed a reasonable balance between Maher's agnosticism and the fanaticism of the interview subjects he shot down. So as to be able to note the similarity in the allusions to these characters, each quotation is listed word-for-word here.

"His two most delightful guests, oddly enough, are priests stationed in the Vatican. Between them, they cheerfully dismiss wide swaths of what are widely thought to be Catholic teachings, including the existence of Hell." ${ }^{87}$

"He makes little effort to be even-handed, although he does speak to an exceptionally jovial Vaticanbased priest who comes across as more rational and open-minded than most of the staunch adherents who are interviewed." 88

"Some of the friendliest exchanges are with Roman Catholic priests, one of whom, the director emeritus of the Vatican Observatory, is much too humorous and worldly to take Bill Maher's creationist bait; he sees evolution as settled science." 89

"The Vatican astronomer eloquently explains why the Bible can't be used to teach science, and a good-humored retired priest says the scriptures are a valuable moral guidebook, but it doesn't matter because people are going to do what they're going to do anyway.,"90

"The Catholics get off easiest in "Religulous," thanks to the inclusion of a couple of refreshing ringers: Father Reginald Foster, a senior Vatican scholar and certified loose cannon; and a Vatican astronomer who calmly makes hash of the creationists who put humankind and dinosaurs on the planet at the same time." 91

"But one comes away from Religulous wishing that Maher had included a few more reasonable people, like the Catholic priest who's also an astronomer and has no problem reconciling faith and science (he's included to help ridicule Creationism)."

"In a small journalistic coup Mr. Maher interviews a Roman Catholic priest in front of the Vatican, who laughingly agrees with him that the fundamental teachings of the Catholic Church are nonsense that are not to be taken literally." 93

A final reviewer who made specific reference to the two men offered a take that appeared (at first glance) to be quite different from the seven above. Oddly, though, he ended up in the same place as the other critics. He began by noting that Maher "pulls some punches" when dealing with Catholicism. But, his reason for making this claim is that he perceived that the when the filmmaker focuses on Catholicism "he interviews the mildest and most modern of men." 94

But, what is it that made these two individuals "mild," "modern,” "delightful," "jovial," "rational," "open-minded," "humorous," "worldly," "eloquent," "good humored," "refreshing," and "reasonable”? ${ }^{95}$ Clearly the criterion is that they choose to reject a number of beliefs that other religious persons who populate Maher's film cling to. For the Vatican astronomer, the doctrinal jetsam is the notion that religion can tell us anything about the world around us. For Reginald Foster, the abandoned beliefs appear to be numerous. He laughs and waves his hand to show he is willing to dismiss large portions of "the old Catholic thing."

To summarize, "lining them up and mowing them down" was one of the most common frames reviewers used to describe how Maher executed his film. The critics had mixed reactions as to whether this was charitable. They also had mixed reactions to whether it was aesthetically pleasing. Many indicated that they perceived Maher to have chosen easy targets, but appear to have as little respect, or affinity, for those targets as the filmmaker did. The true believers of the film are dismissed as much by the critics as by Maher himself. The former indicate that a few alternative interview 
subjects might have been able to stand their ground against Maher's attack and, if so, serve as adequate defenders of the faith. But in painting most of Maher's on-screen debate opponents as religious fanatics and then painting the mild, modern Vatican scholars as acceptable stand-ins, have reviewers conceded the very nature of religion to the film's creators? And, how could such a move be hegemonic?

\section{Discussion}

At one point in Religulous, Bill Maher suggests that he will not be providing concrete answers to questions raised in his film. "The other guys are selling certainty," he says. "I'm on the corner with doubt." In some ways, this is an apt description of the following section. The tones and frames described above provide few answers and a lot of questions about media hegemony theory and its application to spiritual beliefs. To the extent that the questions suggest more research is warranted, the doubt should be comforting to scholars.

One area where there are few questions created by the findings of this study is the reviewers' tone toward the film. Part of the facility of addressing tone is that there is a simple numerical component. And, the positive reviews for Religulous greatly outnumbered the negative reviews. To restate, eleven were positive, four negative and five equally mixed. To many hegemony theorists, this could be seen simply as an example of a leak in the system. In any case, there appears to be no concerted effort on the part of critics to suggest that the film is bad and that viewers should stay away from it. ${ }^{96}$ If reviewers have the power to steer audiences away from a motion picture and cause it to "bomb at the box office," they appear to have made little such effort here.

This in itself might suggest some worthy areas for further study. Might it be possible that the lack of defensiveness reviewers showed toward Religulous was due to its presumed low prestige and/or its unthreatening style? Admittedly, Maher's production is inconsequential in the world of big media. Though it was distributed nationally, its box office figures pale in comparison to big-budget action films. Moreover, reviewers generally classified it as a documentary, a genre with little cultural power in $21^{\text {st }}$ century America. Finally, the satirical style of the film might have lessened concerns some would have about its threat to the dominant order. Reviewers might have questioned whether Maher could really dethrone religion when he is so intent on making us laugh.

If we feel the need to qualify any lack of hegemonic action on the part of reviewers due to the factors listed above, the simple solution is asking additional research questions. For example, would the lack of cultural defensiveness-as measured by the balance of positive and negative reviews - seen here be equally evident if the product reached a bigger audience? For another question, are critics likely to pan big budget fiction films that question key aspects of traditional American belief systems? A third area of inquiry might include the following. Are serious apologia for counterideological religious views welcomed by critics and reviewers, or are they summarily dismissed? Does the medium chosen for by the apologist have any bearing on its critical reception? For the various questions raised above, there are real-world cases to which they can be applied. The book and film renditions of The Da Vinci Code (both highly commercial successes) serve as very good examples, as does Christopher Hitchens' book God Is Not Great which at one time reached the number one spot in the New York Times best-seller list. These two provide plenty of opportunity to further test the extent to which reviewers develop a negative tone toward counter-cultural religious messages.

Before delving into discussion of reviewers' frames, we might first discuss that analysis of them is based on an assumption that has not received adequate attention. The assumption is that movie reviews hold significant framing power. In Cooper and Pease's analysis, for example, the researchers are fully aware that the original story (by Wyoming author Annie Proulx) and the film based on it had their own frames. But, for some unexplained reason the scholars presume the frame created by reviewers is dominant and able "marginalize" the earlier ones. ${ }^{97}$ This is questionable, especially when one considers the nature of framing as it occurs in film reviewing in comparison to framing in news media (something that has received ample research scrutiny). The power of frames seems completely plausible in the latter case for an obvious reason, namely that a frame created for a news event might be the audience's only means of experiencing the event. When people read journalistic accounts of an occurrence, they quite possibly have no direct experience of the original. In film reviewing, writers create a frame for something to which readers have just as much access as they do. We might thus wonder if those who read reviews for a film actually perceive the film within the frame that was constructed by the reviewer. ${ }^{98}$ Evidently, researchers such as Cooper and Pease assume there is a strong relationship here. Otherwise, Annie Proulx's counter-hegemonic short story and the film based on it could not have been marginalized (as Cooper and Pease claim it was) by the manifold reviews written by critics around the country. 
Assuming, then, that reviews do have significant impact on the overall ability of films to change audience members' views, what might we learn from the reviews of a counter-ideological film promoting agnosticism? To what extent might the frames that were used by reviewers alter the strength of the film producer's message?

If we return again to the simplest level of analysis, a frame that we could see as attenuating the power of the comedian's key concept was the one that related to his persona. Media scholars have for some time argued that the media's focusing on personalities has a negative impact on the likelihood that messages will evoke significant understanding and change. ${ }^{99}$ This is extremely difficult to judge, however, as the research that has been done applies to media coverage of politics, not other cultural issues.

Moreover, we need to remember that even though a very large portion of the reviewers studied here focused on Bill Maher as the auteur of this work, the specific thoughts they had about him were quite varied, even contradictory. Though most shared perceptions as to Maher's smugness, some seemed to suggest that this was a significant flaw (almost to the point of steering people from the film) while others saw it as part of the whole package.

Two other areas where reviewers appear to have weakened the force of the film are its overall topic and its interview subjects. To understand the first of these, one need only note that there are plenty of indications Maher's opus is a challenge to all religion. Demonstrating this with a bit of Religulous style humor, a viewer could joke that the title of the film is not Christiansanity, Judumbism or Islame. More directly, any viewer of the film can see that in the intro and conclusion Maher consistently refers to "religion" as the problem he addresses not some sect thereof. ${ }^{100}$ In spite of this, reviewers framed the movie to suggest it questions "organized" faith. Certainly there is a possibility of seeing the reviewers' decision as a hegemonic move. ${ }^{101}$ Audience members, having read these insights could be led to say, "Sure, those organized bodies Maher attacks are dangerous, but not my religion.” A similar point can be made of the reviewers' claim that the filmmaker only interviewed members of "fringe" religious movements. ${ }^{102}$ Viewers who feel that the fringe is not defensible might feel that the mainstream is. And, of course, they might consider themselves part of the mainstream. Such consolation could be seen as working in service of the status quo.

But, this again returns us to conceptual difficulties where more research is needed. How do we know that audiences are willing to do the thought work that is required to follow reviewers' leads and rescue their own faith experience from Maher's smiting of "religion"? And, equally important, what prevents readers from doing other thought work to recognize some of the incongruity of what is presented by reviewers. In the case of Religulous, for example, audiences are asked to believe that those interviewed in the film are members of the "fringe." They are also told that the overall subject of the film is "organized" religion. Are these readers, putting two and two together, really to believe that those who operate on the fringe are more structured, more organized, in their religious practice than are those in the mainstream? Conversely, are the more normal, admirable adherents of faith-the kind who could stand up to Maher's questions had he chosen to interview them instead of the fringe dwellers-practitioners of a less organized style of spiritual activity?

We might be tempted to answer "yes" to these last two questions and suggest that the reasonable people Maher should have interviewed believe in God but are not overtly active in organized faith. Perhaps, using a term that has become de rigueur in American culture today, these potential interview subjects are "spiritual, but not religious." We cannot envision this solution with any logical consistency, though, once we realize one more piece of the framing puzzle provided above. After all, the powerful film critics studied here chose to indicate what an acceptable alternative to the "odd" and "crazy" 103 religionists of the film would be. Two Roman Catholic priests were billed as the model of normalcy and sanity. This creates a rather odd conclusion to the reasoning begun in the previous paragraph. Maher's targets are "organized religion." Roman Catholics are not his targets. Therefore, Roman Catholicism must not be an organized religion. Of course, this is untenable, as Catholicism is arguably the most organized religious movement in the history of humankind.

But perhaps we are applying too much logic to all of this and hegemony works in mysterious ways. Maybe when readers are directed to pay attention to Coyne and Foster, the two "refreshing" Catholics in the film, they forget other elements of the reviews and don't expect consistency. Quite possibly this operates on the level of quick perceptions, not persistent reason. 
Another plausible way of explaining the current case is that this is simply a matter of educated journalists preferring cosmopolitan Catholicism over provincial Protestantism. But, this argument raises additional issues. Certainly the writers are suggesting that the two Vatican scholars are suitable alternatives to the "organized" "fringe." But, reviewers appear to have been so besotted by the "refreshing" duo that they could not fully consider the implications of choosing them as model religionists. Along these lines, only one critic had the clarity of mind to observe that at a certain point in his dialogue Maher really stopped asking the two priests tough questions. In fact, this reviewer even out-Mahered Bill Maher for a brief moment, noting that in the comedian’s Foster dialogue, “Mr. Maher, unfortunately, doesn’t press him on why he wears priestly vestments and presumes to exert religious authority.” 104

Thus, given other writers' silence, one can only assume they are content with a form of religion that has some visible accoutrements (e.g., salaries, titles and vestments). There is nothing to challenge the status quo in that. But, if we go back to the words used by the reviewers when they wrote about Coyne and Foster, we notice the specific features that make the two priests worthy - in the eyes of the critics, at least - of the sinecures they hold. Coyne and Foster are dubious about religion's epistemological potential in the face of science. And, they are extremely dubious of some of its traditional teachings (such as the existence of hell). As one reviewer suggested, this leaves religion as nothing more than "a valuable moral guidebook.","105

A recapitulation and also a connection to earlier research might be in order here. If there is an overall hegemonic message - a message supportive of the dominant culture - in the reviews studied here, it is visible at this point. According to professional critics who filtered Religulous for their readers, broadly attacking religion is completely acceptable. What the reviewers appear to think is exempt from critique is a quiet, private religion that can serve as a basis for public morality. Theological certainty and respect for the traditions of western religion may be held up for ridicule. Holding on to a vague spirituality as a basis for public morality is not. The message seems to be, every society needs "civil religion."

This finding may seem to support one specific side in the body of research related to journalists' religiosity that was presented in the beginning of this paper. But, it actually supports both. On one hand, Lichter, Rothman and Lichter, as well as Olasky, suggested that news professionals hold no strong connection to traditional religion. On the other, Silk and Underwood disagreed, arguing that journalists are deeply indebted to the Judeo-Christian heritage. The position of the latter group of scholars is more nuanced, though, and actually falls in line with the current findings quite well. Silk makes few claims for the theological orthodoxy of the American media, instead saying that they adhere to certain broad teachings of western religion, for example, the need to pursue good works and promote tolerance. Likewise, Underwood paints a picture of journalism that shows commitment only to limited portions of the religious tradition that spawned it. Speaking of Bellah's notion of civil religion, Underwood writes:

"It is no great leap to see Bellah’s concept applied to journalistic institutions. In this view, journalistic values of virtuous conduct, dislike of intolerance, and belief in fundamental moral and ethical precepts may have been moved out of their explicitly religious application and into the secular, public sphere, but they still have their roots in basic religious concepts - in this country, largely JudeoChristian.”"106

There is no disagreement, then, from any of the scholars of journalist religiosity, as to the possibility that film reviewers would be more supportive of Judeo-Christian morality than Judeo-Christian theology. ${ }^{107}$

Accordingly, might we argue that mainstream media—-twenty reviewers from the largest newspapers in the countryhave obliterated the true message of Religulous? Yes, we might. After all, Maher is not interested in abandoning some aspects of religion. He is asking society to completely abandon faith and rely on rationalism and empiricism as alternatives. He says as much in the film. And, in spite of the fact that he briefly loses sight of such for a moment in the delirium induced by Father Foster's nonchalance, he is not interested in relegating religion to a source of morality. He makes clear in his production that he does not even want to give religion that much due, choosing instead to base ethics on experience and reason. ${ }^{108}$ In sum, then, the corporate newspapers really did blunt his message.

But, if we conclude that the comedian's true message has been watered down, does that mean that that religion has been protected, even strengthened through this whole endeavor? Does the critics' argument that religion should be preserved as a source of morality really render service to orthodoxy? Have people of faith really been spared the damage of the provocateur's petard? 
In the process of addressing this, let us not forget that the filmmaker painted a large number of people as crazed zealots and newspaper critics did nothing to contest this. ${ }^{109}$ The movie reviewers simply heaped suffering on suffering, intimating that Maher was probably right. But what was amazing about this is how huge the target group was. It consisted of numerous people who had one thing in common. They adhered to some traditional religious viewpoint with which Maher took exception. One critic from The New York Post was quite direct about this. He wrote:
"The average believer may stiffen and think: I'm not one of these Armageddon nuts, these turbaned freaks who kill cartoonists. But that's only because most sophisticated people help themselves to the moral teachings of religion while discarding the blather about Adam's rib or the Earth being only 5,000 years old. And if you think Scientology and Mormonism are crazy, you shouldn't suspend your disbelief when a priest tells you you're drinking the blood of a guy who's been dead for 2,000 years." 110

The last comment that the writer provides might make us wonder if the questions in the preceding paragraph can be restated again. Though the question relies on an unpardonable pun, it could be restated thus. Has the powerful Roman Catholic Church, with the help of hegemonic film reviewers, really found and destroyed Maher's weapons of mass destruction? The comments from The Post's writer seem to suggest not.

What this alludes to is the fact that in abandoning the fringe dwellers of Maher's film reviewers did much more. They sacrificed many elements that the dominant religious group in American culture would think very important. To illustrate, among the Christian interview subjects of the film, some attempted to defend religious tenets such as the trinity, miracles, and the reliability of sacred texts. The film critics, in suggesting that the movie was about the fringe, may have contributed to the idea that these things are the province of religious extremists and not worth defending. Put in a different form, did the reviewers perhaps write about the film in such a way that it was allowed to engage in a "bombing at the box office"? Might Maher have gotten away with a bit of counter-cultural detonation, even on a small scale?

Interestingly, this question of scale folds back into a discussion of Gramsci and hegemony quite well. A Gramscian approach to religion and media suggests that to move forward (to socialism, specifically), people need to abandon some aspects of religious thought. As one interpreter describes Gramsci's position, socialism will "overcome the mystical and nonsensical tendencies of religion and raise mass consciousness above superstition" ${ }^{111}$ Similarly, media and religion scholar David Dixon has aptly described Gramsci's eschaton (to put this in religious terms) with the following description. "Like Marx, he generally assumed that religion was an opiate of the masses that would eventually fall away as society was 'rationalized.", 112

Where Dixon suggests that a Gramscian view portrays slow, "eventual" change, many hegemony theorists—who as critical scholars are eager for social change - seem to exhibit great impatience. For example, Cooper and Pease, in their analysis of film reviews of Brokeback Mountain, suggest that increased visibility of gay and lesbian characters in mainstream media does not indicate significant progress. More specifically, they write:

"Neither do glowing reviews for a film about the struggles of two same-sex cowboys in the aridly homophobic West, or its popularity among audiences, mean that mainstream America really is prepared to take any significant step to erase what Annie Proulx saw as the destructive and brutal homophobia that her story and the film so starkly document." ${ }^{\text {"13 }}$

What is really being said, then, is that change is not taking place fast enough.

We should note that Cooper and Pease make no efforts to formally correlate the release of Brokeback Mountain to public attitudes toward homosexuality. Similarly, we have no basis here for claiming Religulous has changed American attitudes about religion. Even so, we might point out that shortly after the DVD release of Maher's film, the Program on Public Values at Trinity University released its most recent edition of the American Religious Identification Survey. In data shared by the researchers, the percentage of Americans who claim "no religion" is shown to have risen from 8.2 percent in 1990 to 15 percent in 2008. ${ }^{114}$ The amount and speed of this change might not satisfy Bill Maher. And, hegemony theorists might argue that the change would have been greater if the media were not so defensive of the status quo. Regardless of reservations of this sort, one would have great difficulty suggesting religion in America is unchanged in recent years. 
Might it be that that hegemony theorists need to follow the lead of Bill Maher and exercise more doubt about the theory? And, might it be useful if more scholars focused their attention on counter-hegemonic messages? Much of the research presented early in this paper focused on how structural constraints in the media serve as a means by which the status quo is protected. But, perhaps there are occasions (occasions worth studying) when media "rituals" have little impact on the status quo. Perhaps there are even occasions in which those rituals question or change the norms that we live by. In the case studied here, movie reviewers did what movie reviewers are largely expected to do. They told audience members the "who," the "what" and the "how" of this film. Is it possible that in spite of (or because of) those rituals some of Maher's heterodox ideas changed the minds of his audience? Even if that audience was small, could a succession of such experiences gradually change the American religious landscape? After all, a "petard" is a small bomb to breach a wall, not a large one to vaporize a city. The question is whether "bombings at the box office," even if small, do matter.

Or, to end on a Maher-esque note and return to the metaphor the present inquiry started with, the question can be framed in another way. If those cheap ACME products at the coyote's ready disposal begin functioning properly ten percent of the time, might we not expect that eventually some feathers are going to fly?

NOTES

${ }^{1}$ Ronald Bettig and Jeanne Lynn Hall, Big Media, Big Money (Lanham, MD: Rowman and Littlefield Publishers, 2003$): 8$.

${ }^{2}$ Karl Marx and Friedrich Engels, The Marx-Engels Reader, ed. Robert C. Tucker (New York: W.W. Norton and Company, 1978 ): 172.

${ }^{3}$ Antonio Gramsci, Selections from the Prison Notebooks of Antonio Gramsci, ed. Quintin Hoare and Geoffrey Nowell Smith (New York:

International Publishers, 1971).

${ }^{4}$ Louis Althusser, Lenin and Philosophy and Other Essays, tr. Ben Brewster (New York: Monthly Review Press, 1971), 143.

${ }^{5}$ Douglas Kellner, "The media and the crisis of democracy in the age of Bush," Communication and Critical/Cultural Studies 1 (March 2004): $29-58$.

${ }^{6}$ David Oh, “Arab Americans in the news: Before and after 9/11," Ohio Communication Journal 46 (2008): 15-26.; Kristen Hoerl, "Cinematic jujitsu: Resisting white hegemony through the American dream in Spike Lee’s Malcom X," Communication Studies 59 (Oct-Dec 2008):355-370. Autumn Miller and Susan Ross, "They are not us: Framing of American Indians by the Boston Globe," Howard Journal of Communications 15 (Oct-Dec 2004): 245-259.

${ }^{7}$ Marie Hardin, Julie Dodd, and Kimberly Lauffer, "Passing it on: The reinforcement of male hegemony in sports journalism textbooks.” Mass Communication and Society 9 (fall 2006): 429-446; Angela McRobbie, “Top girls?,” Cultural Studies 21 (Jul/Sep 2007): 718-737. Lindsey J. Mean and Jeffrey W. Kassing, “'I would just like to be known as an athlete,' managing hegemony, femininity, and heterosexuality in female sport,” Western Journal of Communication, 72 (Apr/June 2008): 126-144.

${ }^{8}$ Ellsworth, Elizabeth. Illicit pleasures: Feminist spectators and Personal Best. In, Patricia Erens, ed. Issues in Feminist Film Criticism (Bloomington, IN: Indiana University Press, 1990): 183-196; Mitchell, Danielle. "Producing containment: The rhetorical construction of difference in Will and Grace," The Journal of Popular Culture 38 (2005); Celeste Lacroix and Robert Westerfelhaus. "From the closet to the loft: Liminal license and sociosexual separation in Queer Eye for the Straight Guy.” Qualitative Research Reports in Communication 6 (October 2005):11-19.

${ }^{9}$ See as an example, Ronald Bettig and Jeanne Lynn Hall, Big Media, Big Money (Lanham, MD: Rowman and Littlefield Publishers, 2003). Bettig and Hall list a number of executives who are among the richest people in the world—for example, Sumner Redstone on page 17—who exert power over media content.

${ }^{10} \mathrm{Ibid}$. Bettig and Hall suggest on page 86-87, for example, that the strategic ritual of objectivity eliminates controversial viewpoints.

${ }^{11}$ Ellsworth, Elizabeth. Illicit pleasures: Feminist spectators and Personal Best. In, Patricia Erens, ed. Issues in Feminist Film Criticism (Bloomington, IN: Indiana University Press, 1990): 191.

${ }^{12}$ Ibid, 1052.

${ }^{13}$ Celeste Lacroix and Robert Westerfelhaus. "From the closet to the loft: Liminal license and socio-sexual separation in Queer Eye for the Straight Guy.” Qualitative Research Reports in Communication 6 (Oct. 2005): 12.

${ }^{14}$ Brenda Cooper and Edward C. Pease, "Framing Brokeback Mountain: How the popular press corralled the 'gay cowboy movie.” Critical Studies in Media Communication 25 (August 2008): 265.

${ }^{15}$ Ibid, 250.

${ }^{16}$ Jacques Derrida, “Above all, no journalists,” in Hent DeVries and Samuel Weber, eds., Religion and Media (Palo Alto, CA: Stanford University Press, 2001) 56-93. Note that his term for this was"Greco-Roman-Christian Hegemony.”

${ }^{17}$ Hillary Warren, “The Bible tells me so: Depictions of race, gender, and authority in children's videos.” Journal of Media and Religion 1 (2002): 167-179; Chiung Hwang Chen, “'Molympics,': Journalistic discourse of Mormons in relation to the 2002 winter Olympic Games.” Journal of Media and Religion 2 (2003): 5-28; Erica Engstrom and Beth Semic, "Portrayal of religion in reality TV programming: Hegemony and the contemporary American wedding." Journal of Media and Religion 2 (2003): 145-163.

${ }^{18}$ Robert S. Lichter, Stanley Rothman, and Linda S. Lichter. The Media Elite: America's New Powerbrokers (Bethesda, MD: Adler and Adler, 1986).

${ }^{19}$ Marvin Olasky, Prodigal Press: The Anti-Christian Bias of the American News Media. (Westchester, IL: Crossway Books, 1988): 22-26.

${ }^{20}$ Mark Silk, Unsecular Media: Making News of Religion in America (Urbana, IL: University of Illinois Press, 1995).

${ }^{21}$ Doug Underwood, From Yahweh to Yahoo: The Religious Roots of the Secular Press (Urbana, IL: University of Illinois Press, 2002).

${ }^{22}$ Underwood, 5.

${ }^{23}$ For a description of framing theory and the specifics of the former study's method, see Brenda Cooper and Edward C. Pease, "Framing Brokeback Mountain: How the popular press corralled the 'gay cowboy movie.” Critical Studies in Media Communication 25 (August 2008): 254-255. Other than the added factor of having a group of graduate students agree to frames, the method here was identical to their study. 
${ }^{24}$ Bettig and Hall (2003, cited earlier) suggest that with monopolization, corporate newspapers have greater sway than at any time in history. Not only are the twenty reviewers from these papers read in the largest communities of the country, they are also syndicated and printed again in smaller papers around the country.

${ }^{25}$ Bettig and Hall, 49.

${ }^{26}$ Christopher Kelly, "Religion seen as force of evil in Maher's Religulous," Houston Chronicle, October 2, 2008,

http://www.chron.com/disp/story.mpl/ent/movies/ nowshowing/6036974.html (accessed January 6, 2009) (hereafter cited as Kelly).

${ }^{27}$ Michael Phillips, "Religulous," Chicago Tribune, October 3, 2008, http://archives.chicagotribune.com/2008/oct/03/entertainment/chi-1003-

religulous-reviewoct03 (accessed January 6, 2008) (hereafter cited as Phillips).

${ }^{28}$ Joe Neumaier, "Oh God! 'Religulous' features Bill Maher in 'Real Time’”, New York Daily News, October 2, 2008,

http://www.nydailynews.com/entertainment/movies/2008/09/30/2008-09-30 oh_god religulous features bill maher_in.html (accessed January 5, 2009).

${ }^{29}$ Rafer Guzman, “Religulous,” Newsday, October 1, 2008 (hereafter cited as Neumaier). http://www.newsday.com/entertainment/movies/ny-

etrelig5864082oct01a,0,5655818.story (accessed January 6, 2009) (hereafter cited as Guzman).

${ }^{30}$ Neely Tucker, “'Religulous': O, He of Little Faith,” Washington Post, October 3, 2008, http://www.washingtonpost.com/wp-

dyn/content/article/2008/10/02/AR2008100203426.html (accessed January 6, 2009) (hereafter cited as Tucker).

${ }^{31}$ Kelly.

${ }^{32}$ Wesley Morris, "Maher happily makes a mockery of religion,” Boston Globe, October 3, 2008,

http://www.boston.com/movies/display?display=movie\&id=11384 (accessed January 6, 2009) (hereafter cited as Morris).

${ }^{33}$ Mick LaSalle, "Religulous,” San Francisco Chronicle, October 2, 2008, http://www.sfgate.com/cgi-

bin/article.cgi?f=/c/a/2008/10/02/DDE81391L1.DTL\&type=movies (accessed January 6, 2009).

${ }^{34}$ Carrie Rickey, “Comic Maher has faith in his lack of faith,” Philadelphia Inquirer, October 2, 2008, http://www.philly.com/inquirer/columnists/carrie_rickey/20081002_Bill_Maher_demands_proof_What_he_gets_as_he_spans_the.html (accessed

January 6, 2009) (hereafter cited as Rickey).

${ }^{35}$ Stephen Holden, "Believers, Skeptics and a Pool of Sitting Ducks," New York Times, October 1, 2008,

http://movies.nytimes.com/2008/10/01/movies/01reli.html?ref=movies (accessed January 6, 2009) (hereafter cited as Holden).

36 Tucker.

${ }^{37}$ Maurstad.

${ }^{38}$ Joe Morgenstern, "Bill Maher is the Borat of the God beat in "Religulous," a provocation, thinly disguised as a documentary, that succeeds in being almost as funny as it is offensive,” The Wall Street Journal, October 3, 2008, http://online.wsj.com/article/SB122298339529899629.html (accessed January 6, 2009) (hereafter cited as Morgenstern).

${ }^{39}$ Guzman.

${ }^{40}$ Goodykoontz.

${ }^{41}$ Neumaier.

${ }^{42}$ Goodykoontz.

${ }^{43}$ Kelly.

${ }^{44}$ Stephen Whitty, “'Religulous' finds its target but misses the mark,” Star Ledger, October 6, 2008, http://www.ucc.org/news/movie-reviewreligulous.html (accessed January 6, 2009) (hereafter cited as Whitty).

${ }^{45}$ LaSalle.

${ }^{46}$ Morris.

${ }^{47}$ Kelly.

${ }^{48}$ Roger Ebert, “The punch line is 'apocalypse',” October 2, 2008,

http://rogerebert.suntimes.com/apps/pbcs.dll/article?AID=/20081002/REVIEWS/810020306 (accessed January 6, 2009) (hereafter cited as Ebert).

${ }^{49}$ Goodykoontz.

${ }^{50}$ Kelly.

${ }^{51}$ Phillips.

${ }^{52}$ Symkus.

${ }^{53}$ Puig,

${ }^{54}$ Holden.

${ }^{55}$ Turan.

${ }^{56}$ Phillips; Puig; Rickey; Whitty.

${ }^{57}$ Whitty.

${ }^{58}$ Turan.

${ }^{59}$ Puig.

${ }^{60}$ Colvert.

${ }^{61}$ Kyle Smith, “Omigod!: Maher documentary’s a religious experience,” New York Post, October 1, 2008,

http://www.nypost.com/seven/10012008/entertainment/movies/omigod_131506.htm (accessed January 5, 2009) (hereafter cited as Smith).

${ }^{62}$ Colvert.

${ }^{63}$ Goodykoontz; Rickey.

${ }^{64}$ LaSalle.

${ }^{65}$ Persall.

${ }^{66}$ Kelly.

${ }^{67}$ Colvert.

${ }^{68}$ Tucker.

${ }^{69}$ Ebert.

${ }^{70}$ Symkus.

${ }^{71}$ Symkus.

${ }^{72}$ Holden.

${ }^{73}$ Two reviewers used this term, Goodykoontz and Turan.

${ }^{74}$ Goodykoontz.

${ }^{75}$ Whitty. 
${ }^{76}$ Tucker.

${ }^{77}$ Guzman.

${ }^{78}$ Guzman.

${ }^{79}$ Whitty.

${ }^{80}$ LaSalle.

${ }^{81}$ Phillips.

${ }^{82}$ Goodykoontz.

${ }^{83}$ Turan.

${ }^{84}$ Turan.

${ }^{85}$ Guzman. Rick Warren is a popular evangelical pastor and author of a number of best-selling books. Tony Perkins is head of the Family Research Council.

${ }^{86}$ Maurstad.

${ }^{87}$ Ebert.

${ }^{88}$ Puig.

${ }^{89}$ Morgenstern.

${ }^{90}$ Colvert.

${ }^{91}$ Phillips.

${ }^{92}$ Goodykoontz.

${ }_{93}^{93}$ Holden. As will be discussed in the conclusions, Holden was the only reviewer who turned this in a more negative direction.

${ }^{94}$ Whitty.

${ }^{95}$ I left out "certified loose cannon.” In spite of the fact that Phillips uses that term to describe Foster, he also calls both "refreshing." Quite possibly, he is suggesting that the Catholic church considers him a loose cannon. If the reviewer felt that Foster was a loose cannon, how did the priest also deserve the adjective "refreshing." After all, there were numerous "loose cannons" in the film, from a pastor who thinks he is Jesus Christ, to a Rabbi who denies the holocaust.

${ }_{96}^{96}$ Actually, there is an assumption involved even here, the assumption that film reviews are important for box office success. There is some evidence to suggest it is, but the evidence is not strong. See, J. Eliasberg and S. Shugan, "Film critics: influences or predictors." Journal of Marketing 61 (1997): 68-79.

${ }_{97}$ Brenda Cooper and Edward C. Pease, “Framing Brokeback Mountain: How the popular press corralled the 'gay cowboy movie.” Critical Studies in Media Communication 25 (August 2008): 251.

${ }_{98}$ This would seem to be easy research to conduct, as it would simply require a scholar to do exit interviews of movie audiences to determine if two sets of audiences (those who have read reviews and those who have not) have differing views as to the meaning of the film.

${ }_{99}^{9}$ See for example, D. Rucinski, "Personalized bias in news." Communication Research 19 (February 1992); S. Keeter, "The illusion of intimacy: Television and the role of candidate personal qualities and voter choice.” Public Opinion Quarterly 51 (1987): 344-374; W. Eveland and D.A. Scheufele, "Connecting news media use with gaps in knowledge and participation.” Political Communication 17 (2000): 215-237.

${ }^{100}$ Observant viewers will note that Maher doesn't speak of “organized religion," or "fundamentalism” because he is not focusing on the part but the whole. Faith of any sort (as opposed to reason) is suspect.

${ }^{101}$ We have not basis for delving into the issue but might guess that this could also be a personal move on the part of the reviewers to save face.

Perhaps some of them are religious but do not hold to beliefs that are specifically attacked in the film. Seeing the film as an attack on a narrow brand of faith allows them to feel their religious views are more tenable.

${ }^{102}$ Here too, one might note that this is actually a rather sloppy frame for the movie. Though some of the subjects the host speaks too might be far from the American theological center, others might be quite near it.

${ }^{103}$ Goodykoontz.

${ }^{104}$ Holden.

${ }^{105}$ Colvert.

${ }^{106}$ Underwood, 118.

${ }^{107}$ Some clarification is needed here. Silk and Underwood claim that American media adhere strongly to the moral aspects of western religion. Lichter, Rothman and Lichter, as well as Olasky, would probably agree that, generally speaking, journalists are more connected to biblical morality than biblical theology. But, this second group of researchers would question how consistent journalists' attachment to traditional morality might be. In data from polls conducted by Pew and other organizations, journalists tend to demonstrate more liberal views than the general public on a number of moral issues (e.g., gay rights and abortion rights).

${ }^{108}$ In interviews, Maher openly questions the ethical implications of a number of religious stories (e.g., Sodom and Gomorrah). And, in one interaction with a person of faith he suggests that humans would have learned an ethical principle—one that Maher appears to agree with—by empirical and rational means.

${ }_{109}^{109}$ Maher actually suggests in the film that religious figures such as Moses, Jesus Christ, and Mohamed were psychotic.

${ }^{110}$ Smith.

${ }^{111}$ Rupe Simms, "The politics of religion in plantation society: A Gramscian analysis.” Research in the Social Scientific Study of Religion 10 (1999): 96.

${ }^{112}$ David Dixon, “Aid workers or evangelists, charity or conspiracy: Framing of missionary activity as a function of international political alliances,” Journal of Media and Religion 4 (2005): 14.

${ }^{113}$ Cooper and Pease, 265.

${ }^{114}$ Trinity College, "Catholics on the move, non-religious on the rise," news release, no date, http://www.americanreligionsurveyaris.org/2009/03/catholics_on the_move_non-religious_on_the_rise.html (accessed March 23, 2009). 